\title{
A KANTIAN APPROACH TO ALTRUISM IN RESPECT AND LOVE \\ Yuhang Guo
}

Ph.D. student in Munster University, GERMANY,

E-mail: yuhangguo1986@gmail.com

\begin{abstract}
The requirement of altruism is a defining feature of morality. This apparently makes acting partially, e.g. regarding loved ones, morally wrong and forbidden. The question arises how do we apply or use effective altruism in practice. This paper will seek to answer that question with Kant's categorical imperative, by defending an interpretation of altruism in terms of two subsidiary principles: moral love and moral respect. I will argue that Kantian moral altruism is not merely a matter of logical consistence or even a deconstruction of humanity by reason alone; it must be valued in a more specifically non-formalistic sense that is, moral respect and love. I will also argue that as independent values implied in humanity formulation. Moral respect and love are compatible and can be illustrated the effective altruism.
\end{abstract}

Keywords: Altruism; Respect; Love; Categorical Imperative;

\section{INTRODUCTION}

Kant's ethics is, essentially about altruism. Altruistic rational persons care if the maxim of their action satisfies the categorical imperative, i.e. Kant's Formula of Universal Law (C1) 'act only according to that maxim whereby you can at the same time will that it should become a universal law.' Moreover, treating all persons equally, namely as ends in themselves. Kant's Formula of Humanity (C2) 'so act that you use humanity, whether in your own person or in the person of any other, always at the same time as an end and never merely as a means.' Many consider especially the latter, Kant included, being the most intuitively appealing formulation of the categorical imperative. However, this apparently makes acting partially egoism, e.g. regarding loved ones, morally wrong and forbidden. If it is true that Kantian moral theory requires that we give special consideration to intimates, one might wonder whether we could say that Kantian moral theory is an altruism theory. That is, if Kantian moral theory requires us to give some kind of preferential consideration to one group, how can we still call the altruism? If we think altruism, in contrary to egoism, requires equal consideration or equal treatment at the level of deliberation about moral actions so that our reasons for acting are altruistic, then the proposed understanding of Kantian moral theory would not be an egoism. This view as I understand is merely formalistic view of altruism. By examining the place of relationships in Kantian moral theory, I argue that thinking about the Categorical Imperative in the form of Formula of Humanity (C2) means respect and love for others showing Kantian theory not only allows but also requires that we give special consideration to intimates, which might provide a way of understanding effective altruism.

In this paper, I begin in section 1, with an overview of difference between a Kant's account of the altruism of morality and the purely formalistic altruism. In section 2, I outline 
the current debates on concept of moral altruism. In section 3, I respond to this critique by elucidating altruism in terms of two subsidiary principles, moral love and moral respect. In section 4, I will show how moral respect and love are compatible and applied to a number of examples (duty of beneficence) to illustrate how an effective altruism is possible.

\section{THE TENSION BETWEEN FORMALISTIC AND NON-FORMALISTIC ALTRUISM}

There are different ways to understand altruism, truthfully or not truthfully. The misunderstanding, from both critics and interpreters imply that altruism requires either equal treatment or equal consideration for everyone. This view of altruism links with absolute equality. In the practical scenario and circumstances, this means that our friends, family, and significant others deserve either the same treatment or at least the same consideration in our decisions as strangers, in my view neither Kant nor many scholars agree that Kantian altruism is essentially formalistic. If, indeed, Kantian altruism is merely formalistic we would, of necessity, regard him personally as a cold, unfeeling person, and his moral philosophy as unenlightening with regard to human sensibilities and rationality.

This view of purely formalistic altruism as the overriding factor in all moral decisions does not present the best way to think about the kind of impartiality required by Kantian moral theory, rather than being caught in the formalistic quagmire. By exploring Kant's altruism more deeply and by turning to a non-formalistic, i.e. the moral respect and love, understanding of his work, we may discover philosophical rigor, intellectual value and practical application. While purely formalistic impartiality is essentially a negative way to understand Kantian altruism, moral respect and love as two fundamental moral feelings offers a fresh approach, albeit often ignored by Kantians that is positive and productive.

Logical Consistency: The Narrow Emptiness Account of Altruism

It has been generally considered that Kant's moral philosophy is essentially about his categorical imperative. There are numbers of categorical imperatives ${ }^{1}$, the first formulation: Act only according to that maxim whereby you can at the same time will that it should become a universal law without contradiction. $\mathrm{C} 1$ describes the procedure moral decision, it has its formal outweigh in action, Kant says moral law must be universalized because it is not only empirically valid, but also objectively valid. Then the question comes out: how the

\footnotetext{
${ }^{1}$ Many Kantians offer this distinction. For instance, non-formalists read Kant as departing from formalism due to $\mathrm{C} 2$, given Kant's expression that there must be "something the existence of which in itself has an absolute worth." By a process of elimination that $t$ something must be persons by virtue of their capacity for rational agency. The absolute worth of persons or rational agents comprises an independent order of value which precedes and grounds the moral law. On the other hand, Kant is read as a moral formalist due to C1 and C3.In the first case, Kant is understood as saying that there is a procedure for testing maxims to that allows us to test them for universality thereby constructing rational maxims. Alternatively, according to C3, Kant is understood as saying that the stance of the members of an ideal kingdom of ends defines what is right. This view holds that "morality consists, then, in the reference of all action to the lawgiving by which alone a kingdom of ends is possible.", however, such a kingdom is "admittedly only an ideal." The members of such a merely ideal realm would construct the laws for themselves as the ones to bind all of us. For example, ideal legislators pass ideal laws that impose moral behavior. However, the content of the moral law itself is not implicitly self-legislated. That is, the moral law by which we are bound is a universally valid maxim. However, in an ideal realm of ends the law will not be the outcome in accordance with what we do. See Paul Formosa Is Kant a Moral Constructivist or a Moral Realist'?
} 
individual will can be the universal will. ${ }^{2}$ This question is not only for the first formulation, but also for the altruism. Understanding altruism can be the way of our understanding Kant's first formulation. Kant's first formulation itself is formal (not formalistic), but the reconstructions and interpretations by Kantians are different. In understanding Kant's first formulation, the narrow formalistic notion of impartiality, as a procedural constraint on the process by which particular moral principles are determined without recommending the substantive principle of altruism; it directs agents to assume the stance of a disinterested judge and treat all persons equally. This seemingly simple principle reminds us the ancient Greek democracy that had no commitment to the equality of persons. The principle of social justice proposed by Plato and Aristotle 'treats the unequal unequally and the equal equally.' An example of formalistic altruism can be found in discussion of the grain-stealing problem:

A farmer who wants to steal his neighbor's grain wonders why this is not permissible. From an external point of view, stealing grain is morally impossible because of common human will which subsequently creates a self-contradiction. In this case, the farmer's private will contradicts the universal will which harks back to the democratic version that complies with universal progression. Therefore, there is nothing morally impermissible about stealing another's grain until the majority of framers who disallow stealing grain create specific rules or laws prohibiting theft. However, such a universal progression reveals the pitfalls of legal positivism which states that we receive rights as a result of laws legislated and enforced by a governing authority. Further, then ideal of a democratic universal will does not go far enough since, returning to our example, the farmer's theft will be morally indifferent. In the end, therefore, a farmer who steals his neighbor's grain is only considered immoral after some positive law is established to prevent stealing grain. Before this decision is made, the democratic universal will results in a war of conflicting interests.

While this purely formalistic notion of altruism in Kantian formality highlights the importance of the universal will, what occurs when my personal will conflicts with the universal will? This question cannot be solved by depending upon the democratic version, which makes moral decisions by relying upon the non-inter-subjective views of the majority. Again, referring back to our example originated by Kant, I may pursue at least two options in order to arrive at a majority opinion with regards to stealing grain. First, perhaps I can ask my neighbor's and others' attitudes about stealing gain. Or, second, perhaps, as members of the agricultural community we could vote on this issue.

While this example may be illustrative, we must note that Kant's notion of altruism is obviously more complicated since his view may be characterized as closer to the impersonal totalitarian view, which is abstract, impersonal and non-inter-subjective. In this case, stealing grain is not only incompatible with the will of a neighbor, but with the will of any owner who has monetary wealth or property; therefore 'no one in particular' is identified. Nevertheless, when individual will conflicts with universal will, individual will is morally forbidden. In other words, there is no need to balance individual and universal will.

This view, according to Kant, holds that 'in a conflict, the universal will is more powerful than the private will. ${ }^{3}$ Still, such a view creates new questions: How do I absorb an obscure and impersonal point of view? As an agent living in the real world, the universal

2 For helpful discussion of other generalization and universality principles, see Marcus Singer's 'Universalizability and the Generation Principle' in Morality and Universality, ed. Potter and M.Timmons, (Dordrecht: 1985).

${ }^{3}$ M.29:621 
will does not come automatically as an epiphany if one strays from the universal will. How, then, can one recognize the universal will? Kant encountered while reading Rousseau's The Social Contract. In assuming this position, Kant seeks to mediate between universal and individual will. ${ }^{4}$ The Rousseauian Universal Will explanation which stresses everyone's best interests or the common good is also invalid. In Kant's view, ostensibly, the idea of a general will which results in what is ultimately best for everyone is likely naive given modern political perspective. However, this does not appear to be the case.

A purely formalistic notion of altruism does not answer such questions satisfactorily. I hold that a Kantian approach of altruism offers a better alternative to the narrow impersonal stance elucidated here. Because Kant seeks to grasp human understanding and believes humans are capable of both engaging and implementing speculative actions in accordance with the common good, humans are therefore able to pursue a non-formalistic, public conception of the good. I propose that such a view constitutes the archetype of Kantian nonformalistic altruism.

According to formalistic altruism, neglecting others in need might be permissible, provided that one does not desire to receive help in the future; such a stance would at least be coherent. However, Kant may well have held that the formalistic requirement of altruism is not enough. He adds the positive duty of beneficence in the illustration of $\mathrm{C} 1$ to forbid negative formalistic duty, i.e. making promises that serve self-interest. Given this aim, altruism must describe the ideal conditions under which impartial principles can be selected and justified.

In order to extend my discussion further, I now turn to an examination of Kantian non-formalistic altruism.

Before we make this move, I will first look at a Kantian principle of beneficence. Kant affirms that our personal relationships can affect which beneficent action we choose to do: 'in acting [beneficently] I can, without violating the universality of the maxim, vary the degree greatly in accordance with the different objects of my love (one of whom concerns me more closely than another). ${ }^{5}$ Because many people sense a conflict between their obligation to help others and their desire to benefit intimates, is there the proper place for non-formalistic Altruism?

\section{THE VALUE OF NON-FORMALISTIC ALTRUISM}

In the Groundwork, Kant divides duties into two types: perfect duties and imperfect duties. We have each kind of duty both to self and to others. ${ }^{6}$ Perfect duties are duties we have to others and ourselves that require us to act or refrain from acting every time a situation involving that duty arises. Examples of perfect duties for Kant are the duties to keep promises, not to lie, and also duties of justice. The duty of beneficence is an imperfect duty to others. Perfect duties are the obligations in the sense that we must follow the moral law; we must not lie and kill ourselves. While the imperfect duty constrain the obligation as choiceable, in this paper, I do not seem to overlook the formal requirement of perfect duty, the formal obligation or necessity is indeed the basis of Kant's moral philosophy. The reason I take the turn to explain the example of imperfect duty is, the duty of beneficence is closer with what I term the non-formalistic altruism. In the sense that as the phenomenal being, we overcome our desire or empirical constraints to follow the moral law. Both the perfect duty

\footnotetext{
${ }^{4}$ Jean-Jacques Rousseau. The Social Contract and other later political writings, translated by V.Gourevitch (Cambridge: Cambridge University Press, 1997) chapter 3.

${ }^{5} M M 6: 452$

${ }^{6} \mathrm{Gr} .421-423$
} 
and imperfect duty will point to the value of altruism, that is, our humanity; the formal aspect(in contrast to the mere formalistic) in perfect duty is within us, I will show how the imperfect duty is equivalent with the value of non-formalistic altruism.

In the case of the duty of beneficence, we are required to act beneficently on some occasions. The actions we choose to do as part of our duty of beneficence are up to us. We may volunteer for a charity or we may donate money. Both would count as acting on our duty of beneficence.

However, In the Metaphysics of Morals, Kant says that the commands of morality apply to everyone, "without taking account of his inclinations, merely because and insofar as he is free and has practical reason."7 Because morality is supposed to apply to everyone "without taking account of his inclinations," one might think that we are not allowed to take our personal relationships with others into account when we are deliberating about moral action because of our inclination towards intimates and our desire to act in ways that benefit them. If this view is right, then it looks as though we are not allowed to act for reasons which would express partiality for someone-we are not allowed to act on relationship obligations. Such actions would be excluded by Kantian moral theory. The following question will help direct our examination of non-formalistic impartiality: How exactly is the Kantian duty of beneficence determined by non-formalistic impartiality rather than formalistic altruism?

To provide an answer, consider this scenario: I have an over-abundance of resources and my neighbor is about to die from starvation due to his poverty. I am fully aware of my neighbor's suffering and of the steady decline of my food resources. According to the narrow formalistic altruism stance, which considers moral law as equivalent to logical coherency, I am not required to act to meet my neighbor's need especially if I do not intend to accept charity in the future; this position appears completely rational. What reason could I have for not feeding my neighbor? My reason cannot be a mere logical consistency, for if I am, indeed, indifferent about everything I would also be indifferent about relinquishing some of my wealth to feed my neighbor. Let us assume, then, that I am specifically indifferent about by neighbor's suffering. In reality, even though I know that I could prevent my neighbor's suffering by giving him some of my surplus, my real attitude is that I prefer holding on to my surplus rather than acting to save my neighbor from starvation. It is irrelevant whether his life has no value or is of minimal value to me. In neglecting to feed my neighbor, I show that I am partial to sustaining my over-abundance when compared with his life.

Now, assume that my neighbor's life negatively effects my happiness because he regularly disturbs the peace with his cries of hunger that keep me awake at night, even though his behavior has no substantive impact on my conscience. By allowing him to starve, not only would I get to keep my surplus, I would also get rid of a disturbance that makes me unhappy. However, if I act from a duty born of beneficence, I clearly choose to benefit my neighbor in preference to retaining my surplus and ensuring my happiness.

Nevertheless, such seeming self-sacrifice will still not be morally good if it can be affected. That is, no matter whether the ultimate effect is positive or negative, humans may well hold to the supreme moral value which motivates us to regard others as ends in themselves not merely means. Therefore, $\mathrm{C} 2$ is not merely a negative assertion, as the narrow formalistic account of altruism. The supreme value espoused in $\mathrm{C} 2$, is, then, not too

${ }^{7} M M 6: 217$ 
formalistic to guide our action; it possesses concreteness or substantive matter that informs an altruistic approach to others.

Furthermore, when Kant considers a situation similar to the one previously described, he says that the character of the dutiful benefactor has incomparable moral worth. ${ }^{8}$ Such moral worth, I argue is the non- formalistic value of altruism for Kant.

Another case worthy of consideration emerges when Korsgaard objects to Dierichson's example of a woman who has decided to consider a maxim that states, ${ }^{9}$ 'If I give birth to a baby weighing less than six pounds, I shall do everything in my power to kill it.' While Dietrichson opposes this maxim given that it fails to mention the mother's reason for killing the child, Korsgaard correctly points out that we can pose a maxim stating that 'killing children that tend to cry at night more than average in order to get enough sleep' is not a logical contradiction with the mother's maxim in Dietrichson's example. While these examples of allowing a neighbor to starve or murdering children in accord with some rule of action may appear extreme, they can and, indeed, have occurred in our world. Therefore, if we choose to impartiality consider the interests of all concerned parties in a given situation, such a course goes well beyond the requirements of a merely formalistic notion.

These cases, therefore, demonstrate that the narrow emptiness notion of altruism that relies on logical coherency is fallacious, whereas the non-formalistic notion of altruism is not subject to such errors. As we now turn to consider the broad emptiness charges as well as the nature of humanity, we will also see that the non-formalistic notion of altruism remains plausible.

\section{Broad emptiness account of altruism}

As we have seen the narrow formalistic account of altruism implies that one must be maintain nothing more than logical consistency. This characteristically views impartiality as a requirement of morality, which, in turn, leads to the nature of humanity. While such a position might be well accepted as a purely metaphysical consideration, in my view, Kant's theory is provoking not because of its attractive form, but rather because of its practical benefit which enables us to comprehend humans, including ourselves, while also serving as a guide for moral action.

With regard to these controversies, Kant seems to advocate that the members of the moral community are to set aside their personal interests in consideration of the principles that should govern the moral community. For example, suppose that our community decides to ban the right to own and hold private food supplies in order to achieve the common good of eliminating hunger. As a result, everyone would be allowed to enter any household and eat whatever they need. This and other like moral quandaries raise the issue of how to morally balance the ultimate needs of humanity or community ends with private ends. Paul Guyer explains the possible systematic connection of these two seemingly competing ends:

There is no guarantee that in any given circumstances that there will be any maxim of action that could be adopted by any single agent that will also be compatible with all those ends. ${ }^{10}$ A genuine moral community, therefore, requires that we rise above our private interests and ends so that we can arrive at a decision that ensures harmony in our community

\footnotetext{
${ }^{8}$ Gr.398-399

${ }^{9}$ For details about the example See Christine M. Korsgaard's Kant's Formula of Universal Law and see When Is a Maxim Fully Universalizable'. Dietrichson

${ }^{10}$ Guyer (P.) (1995). the possibility of the categorical imperative. The Philosophical Review, 104 (3), pp. $353-$ 385 .
} 
by achieving community ends. In this sense, non-formalistic impartiality ensures that no particular person's or group's ends receive special consideration.

Given this interpretation of C3 (the kingdom of ends formula), Kant holds that the moral community as a kingdom of ends will not be possible if we justify a particular action or maxim solely on the basis of satisfying personal ends. However by balancing our legitimate personal considerations with the interests of other particular individuals as well as the 'common or social interests' we achieve a moral resolution. For Kant, then, altruism determines the will and harmonizes with his theory of value. Therefore, this position withstands the broad emptiness account.

However, this view of the good which prefers the concerns of our neighbors does not fit with the abstraction Williams proffers, noted above. In fact, Williams complains that Kant's view of humans essentially divorces our will from our individuality. However, according to $\mathrm{C} 3$ (the formula of the kingdom of ends), this charge would be dismissed because Kant defines the kingdom of ends in the following way:

I understand by a 'kingdom' the systematic union of different rational beings through common laws. Now, since laws determine ends as regards their universal validity, we shall be able-if we abstract from personal differences between rational beings, and also from all the content of their private ends to conceive a whole of all ends in systematic conjunction (a whole both of rational beings as ends in themselves and also of the personal ends, which each may set before himself); what is we shall be able to conceive a kingdom of ends, which is possible in accordance with the above principles. ${ }^{11}$ Kant's ultimate assertion is that even if rational agents abstract away all of their personal ends, they can still conceive of themselves as agents. One can always act by relying upon the reason provided by the end of humanity as an end in itself. Respect for humanity or rational nature is an end for all rational beings and, as such, it provides a rational agent with a reason for an action that is distinct from any contingent end the agent may have. Hence, Kantian altruism is not impersonal and indifferent to others, and it is not of course, merely formalistic.

\section{MORAL RESPECT AND LOVE IN HUMANITY FORMULATION}

In section 1, we have seen that personal relationships are not in some fundamental way incompatible with Kantian altruism, I have given the response that Kantian moral altruism is not merely a matter of logical consistence or even a deconstruction of humanity by reason alone; it must be valued in a more specifically non-formalistic sense. My task, in section 2, has shown that the non-formalistic altruism has the mandate effect on our moral decision, but how the element of altruism could effect as necessity for moral decision, it needs to say more. In this sense, the function of respect and love as the moral incentive allows me to rebut a further charge moved against the purely formalistic altruism. Formalistic altruism conceals change and difference in character, Kant's conception of impartiality is exactly helpful because it links the role of respect and love as a moral incentive. Then the general disputes arise on how can the impartiality derive moral respect and love in reading categorical imperative, in another sentence, how moral respect and love could apply altruism in Kant's genuine usage.

In this section, I would argue moral respect and love are at the core of Kant's theory of altruism. Many formalists would agree that Kant's ethic give some attention to these notions, but none of them have recognized that they are independent values in Kant's system. The broad emptiness charge urges that impartiality is products of formalistic willing.

${ }^{11} \mathrm{Gr} .74$ 
I would suggest, however, that the broad emptiness charge dismisses the non-formalistic aspects of values. Kant's ethic needs and indeed possesses a non-formalistic component in order to 'complete' judgments about obligation and goodness. In the rest of the paper, I consider whether the concept of respect and love appropriately and fully expresses the value of humanity, i.e. the non-formalistic component of altruism. In order to explore these ideas further, we will now consider moral respect and love in greater detail.

\section{Moral respect as value of humanity}

In Groundwork I, Kant clarifies respect marks morally worthy actions. The presence of respect is a warrant that the agent acts out of duty, that is, independently of inclinations. ${ }^{12}$ And given the second formulation [A]ct so that you treat humanity, whether in your own person or in that of another, always as an end and never as a means only This certainly sounds like we ought to 'respect persons', and in a sense we should. But in what sense? Some interpretations of the phrase require that we 'value' each person's individuality, his distinctiveness as a human being, and that everyone be given effective rights (subject of course to non-injury to others) to develop that distinctiveness. It is supposed that you must treat me in accord with my own purposes - determined by my hopes, dreams, fears, desires and not your own. Within some reasonable limits, determined by your own and others' needs, you should 'respect what I want' and be supportive, both of my right to pursue it, and of its actual pursuit. This attitude is usually considered to entail respect for my autonomy as an individual: I am to be my own judge of what is good for me and of how I should develop as a person.

Kant's account of respect as a mark of moral agency and as the evaluative attitude due to persons expressed in $\mathrm{C} 2$ has been the target of severe criticisms. The illusion that Kant respects persons comes from ascribing contemporary meanings to purely technical terms within $\mathrm{C} 2$; we would be in a better position to do so once we appreciate C2. As Rawls tells us that those who think of Kant's moral doctrine as one of law and guilt badly misunderstand him. Kant's main aim is to deepen and to justify Rousseau's idea that liberty is acting in accordance with a law that we give to ourselves. And this leads not to a morality of austere altruist command but to an ethic of mutual respect and self-esteem. ${ }^{13}$

Kant says little about what respect is, either as a feeling or as a feature of moral consciousness, and what he does say reveals what I think is a blind spot in his argument. For example, he adds in a footnote that 'it could be objected that I only seek refuge, behind the word respect, in an obscure feeling, instead of distinctly resolving the question by means of a concept of reason. ${ }^{14}$ Respect has a duality of nature that seems to embody a contradiction.

One might also have supposed that Kant had something more abstract in mind, and I shall argue that this is indeed the case. However, on Kant's view, the concept of respect is neither ancillary nor subordinate to rational agency: as subjective experience of rational agency, it is the independent value of humanity.

On Kant's view, the feeling of respect is the mark of moral agency, Respect is a feeling that is generated by the agent's reflection on the nature of her own agency. It is not directed to anybody in particular, but to the very idea of rational agency, which is characterized by self-mastery and self-legislation. We are capable of setting ends of our own,

\footnotetext{
${ }^{12}$ Ibid,27-29

${ }^{13}$ Rawls, A Theory of Justice, op. cit. P.256. Rawlsian self-esteem includes “a person's sense of his own value, his secure conviction that his conception of his good, his plan of life, is worth carrying out". We should be able to "pursue [these plans] with pleasure" and "take delight in their execution".

${ }^{14}$ Gr.402/56, footnote
} 
by exercising practical reason, that is, by engaging in the activity of law making. It is on this ground, Kant argues, that respect qualifies as the appropriate evaluative attitude toward persons, that is, beings capable of making laws and, therefore, setting ends. We value persons insofar as they are endowed with reason, hence capable of lawful activity and thus susceptible to morality. Respect for persons is held equivalent to the reverence for this capacity, in which resides our humanity, as the independent value in ourselves.

\section{Moral love as value of humanity}

I have established that respect is perception of boundaries between different units of agency, and to this extent, it is essential to express the value of altruism or humanity. The question remains whether respect is indeed the only moral attitude appropriate toward persons. My suggestion is that we can regain a richer moral vocabulary for valuing others by a Kantian approach to altruism. ${ }^{15}$ Kant pairs respect for persons with love of mankind, as attitudes that have humanity as their object. They are both moral feelings and to this extent, they govern the configuration of the will and are reflective or deliberate.

Love as a moral feeling appears as one of the four sensitive basic concepts in the Metaphysical Principles of Virtue. Like the other sensitive basic concepts, love is cardinal to moral agency; without these concepts, we would be "morally dead", that is, unsusceptible to morality. ${ }^{16}$ As Kant explains love, it seems that a pathological sensibility is necessary to have moral sensibility. ${ }^{17}$ Our natural susceptibility to rejoice with others or to feel pity for them is a sort of contagious inclination, whose basis is sensitive, thus not free (communio illiberalis, servilis). However, to make use of such susceptibility for furthering active and rational benevolence is dutiful. ${ }^{18}$ This genuine compassion is grounded on our natural inclination to sympathize with others, but it is deliberate, and thus counts as a moral activity (communio sentiendi liberalis). No form of moral feelings is conative in the sense in which pathological feelings can be, that is, as compelling drives.

Acting on a motive of love not only makes an action morally wrong, but also, the moral love is in essence, can be our motive for acting. If the motive of duty is also present as a secondary motive, then the action can be morally right for a Kantian. As a secondary motive, duty serves only to limit those actions which would otherwise be morally wrong. If an action is morally correct or permissible, we can perform that action. This response shows that personal relationships can be part of a Kantian moral theory because we are still allowed to do actions for intimates and the love that grounds that relationship can be our motive for acting.

To be sure, it would object that this kind of love has little to do with people, but (like respect) it has to do "with rationality in their breasts" ${ }^{19}$. Not surprisingly, my rejoinder is that this objection fails against Kant's account of love for the same reasons why it fails against Kant's account of respect. The difference between love and respect is reflected in the nature of duties that they respectively ground. The duty of respect is merely negative; it amounts to a duty to have one's self-esteem constrained by the acknowledgment of the dignity of others.

\footnotetext{
${ }^{15}$ Murdoch claims that because of a generalized endorsement of Kant's conception of agency, contemporary philosophy has lost (or disposed of) the moral vocabulary for expressing the complexity of moral life and mutual recognition. Contrary to Murdoch, I have argued that to repossess the conceptual ability to appreciate and value mutual recognition in all its forms, we are better off reclaiming Kant's conception of moral sensibility, agency and deliberation.

${ }^{16}$ Kant, 1797, Metaphysics of Morals, trans, Lewis White Beck P. 400

${ }^{17}$ Ibid 453, 457

${ }^{18}$ Ibid

${ }^{19}$ See Murdoch, Ibid. P.215
} 
It is thus to be regarded as a strict duty, contrary to duties of love, which are broad. Despite the difference in their phenomenology, Kant remarks that love and respect are generally present together. In the second part of the Elements of Ethics, dedicated to duties of love to others, we read: Love and respect are the feelings which accompany the exercise of these duties toward others. These feelings can be considered separately (each on itself), and they can also exist separately, (love for one's neighbor, though he deserve little respect: also necessary respect for any man although he be judged hardly worthy of love). But they are basically, according to the law, always combined in one duty, although in such a way that sometimes one duty is joined as accessory. Although love and respect differ in the way they ground the duties, and each of them suffices as a motive for duty, they generally occur together. They work as concurrent attitudes, present together in the mind of the moral agent, who is therefore loving and attentive to others, respectful and caring. If the motive of action is respect, and love is an accessory, we may say that the agent acts out of a loving attention. If the motive of action is love and respect is an accessory, the compound attitude is a kind of reverential love. Although respect and love may concur in the practice of morality and concurrently inform our interactions, they are distinct functions of our moral sensibility and govern our relations in different manners, they both express the value of the humanity.

\section{MORAL RESPECT AND LOVE: APPLY ALTRUISM IN C2}

In section 3, I show that Kant's respect and love has the concrete value and exhibit a similar phenomenology and work likewise. Respect and love for humanity or rational nature is an end for all rational beings. I argue that both these concepts signal the awareness of agential boundaries. Insistence on the similarity between respect and love does not impoverish the vocabulary of value humanity; rather, it allows us to restore both of them as distinct concepts.

C2 points out non-formal and concrete value of moral law, formalistic understanding $\mathrm{C} 1$ has given the altruism the formalistic manner, as in Kant's expression that the form of categorical imperative is various, but there is only one categorical imperative. If we understand C2 correctly, how C2 could link with C1? How we apply the meaning of impartiality in $\mathrm{C} 1$, through moral respect and love in $\mathrm{C} 2$ ? We are morally required always to treat others with respect. How to understand the difference Kant expressed here? To confound them, or to opt for one of them at the exclusion of the other, is to deplete the basis of our personal relations. Is Kant's respect egoistic? Or, is Kant's love egoistic?

Altruism is not always required of us at the level of our direct actions. We can show partiality in our actions as long as our general principles approve partiality in those situations. For example, we can show partiality for our parents by acting in ways that honor them because we can see good reasons for the principle, "Honor thy mother and father." It may be misunderstood that the Kantian would require of the man contemplating the reasons he has for saving his wife over the stranger. In Kantian moral theory, personal relationships affect our conception of the Good. Rather than thinking of the motives that arise out of personal relationships as in direct conflict with the motives of altruism. Moreover, it is morally appropriate (not in any way inappropriate) in these circumstances to act on these reasons. The reason that I save my wife is, "that I love her or that she's my wife." These are the reasons on which one acts, and the actions they support express the relationships they refer to. It would be one thing if the husband paused to weigh the claims of his wife against those of others he might save; that would speak against his having the kind of attachment that might be hoped for by his wife. What the Kantian requires is only that he not view his 
desire to save his wife as an unconditionally valid reason. This does not stand in the way of the direct expression of attachments in action.

Kantian moral theory does not require that we always act from altruistic reasons. What it does require, is that we understand that sometimes, the circumstances of particular situations will be such that the reasons we have that come from particular relationships will be not enough to justify our acting on that reason in other circumstances. We must be aware of the context in which our action takes place and what additional considerations have to be taken into account because of the context. Making the ends of a human individual my own, like the duty of respect itself, is a "wide" obligation and an "imperfect" duty, ${ }^{20}$ there is no telling how much sacrifice it is appropriate for me to make: I have to decide that for myself. Finally, I do not have to take your word on what is good for you. On the contrary, you must make your own decisions, but I do not have to support them if they seem to me wrongheaded or immoral. To 'respect' you is not to support your amoral desire, Instead I respect you by making your moral end as a person, which is to go into law, my own. This is Kantian respect. It subordinates the pursuit of even the most innocently self-regarding desires to the dictates of an austere conclave of noumenal selves, in whose deliberations ordinary people, empirical selves, have no role.

\section{CONCLUSION}

In this paper, I have presented a resolution of the problems arising from the versions of altruism mostly by reconsidering them in a non-formalistic sense in Kant's categorical imperative. As we have seen, the broad emptiness account of altruism is an adaptation of the traditional emptiness account. This charge claims that the most distinctive and important feature in Kant's altruism is not his claims about the particular ethical duties that we owe to each other, but his views about the nature of value. In other words, moral action wholly exists deep inside of me rather than elsewhere. However, I argue that the possibilities for a formal theory of willing or the nature of value are based on Kantian universalization whereas the broad emptiness doctrine supports a theory rooted in the nature of value and employs different ways that in the end misunderstand the content of moral law.

In contrast, I pose a non-formalistic altruism constitutes a rival Kantian theory of altruism. I further claim here that the core character of Kant's value theory rests on two primary values within Kantian ethics: respect and love. I have argued that each single value is an independent value, which many formalists would probably have not recognized given their stance and given that their formalist interpretation. This interpretation holds that moral respect and love, which arise from formalistic impartiality, are unable to determine the will while at the same time claims that these values cannot be derived. Therefore, I have proposed that Kant's ethics possesses a non-formalistic component to provide 'complete' judgment that speaks of and informs actions. Friends share the same projects, and depend on each other for the fulfillment of their ends, which pertains both to love and respect. More generally, as a moral maxim, love grounds actions of benevolence. Recognizing the dignity of others requires that we appreciate their rationality, and the rationality of their ends. On some occasions, this requires that we help them in the pursuit of their ends: This is a form of

${ }^{20}$ The best way to begin seeing how FH is supposed to be applied is to look at Kant's four examples in the Groundwork. Kant's examples are of suicide (perfect duty to oneself), lying (perfect duty to others), developing one's talents (imperfect duty to oneself), and contributing to the happiness of others (imperfect duty to others). 
love humanity. This is also my initial concern that how to apply altruism in terms of moral respect and love in $\mathrm{C} 2$.

\section{BIBLIOGRAPHY}

[1] Immanuel Kant, Groundwork of the Metaphysics of Morals, translated by M.J. Gregor In Practical Philosophy (Cambridge: Cambridge University Press, 1996)

[2] Immanuel Kant, Critique of Practical Reason, translated by M.J. Gregor (Cambridge: Cambridge University Press, 1996)

[3] Immanuel Kant, Critique of Pure Reason, translated by P. Guyer and A. Wood (Cambridge: Cambridge University Press, 1997)

[4] Bernard Williams, Persons, Character, and Morality, in Moral Luck. Cambridge. Cambridge University Press, 1981.

[5] Hill Thomas E.Jr. Dignity and Practical Reason in Kant's Moral Theory. Cornell, Cornell University Press, 1992

[6] James. Bohman, Public Deliberation: Pluralism, Complexity, and Democracy, Cambridge: MIT Press, 1996

[7] Kohl Harald, Kant's Gesinnungsethik. Berlin, New York, 1990

[8] Korsgaard Christine, Kant's Formula of Humanity. Kant-Studien v.77, 1986

[9] Korsgaard Christine, Kant's Formula of Universal Law, Pacific Philosophical Quarterly, v.66, January 1985

[10] Paton, H.J. The Categorical Imperative. Hutchinson's University Library. London,1947

[11] O’Neill Onola, Acting on Principle. New York: Colombia University Press, 1975

[12] O’Neill Onola, Constructions of Reason. Cambridge: Cambridge University Press 1989

[13] Oliver Sensen. Kant's Conception of Inner Value. European Journal of Philosophy, 2009

[14] Patricia Kitcher. Kant's Argument for Categorical Imperative. Noûs.2004

[15] Paul Formosa. Is Kant a Moral Constructivist or a Moral Realist? European Journal of Philosophy, 2010

[16] Rawls John, A Theory of Justice. Cambridge: Harvard University Press 1971,

[17] Rawls John, The Dewey Lectures, Journal of Philosophy, 1980

[18] Sidgwick Henry. The Methods of Ethics. London, 1907

[19] Silber John R. Procedural Formalism in Kant's ethics. Review of Metaphysics v.28, 1974 